\title{
Infective Potential of Sporangia and Zoospores of Phytophthora ramorum
}

\author{
T. L. Widmer, Foreign Disease and Weed Science Research Unit, USDA/ARS, 1301 Ditto Avenue, Fort Detrick, \\ MD 21702
}

\begin{abstract}
Widmer, T. L. 2009. Infective potential of sporangia and zoospores of Phytophthora ramorum. Plant Dis. 93:30-35.

Phytophthora species produce sporangia that either germinate directly or release zoospores, depending upon environmental conditions. Previous Phytophthora spp. inoculation trials have used both sporangia and zoospores as the inoculum type. However, it is unknown what impact propagule type has on disease. Rhododendron leaf disks were inoculated with $P$. ramorum zoospores $(75,500$, or 2,400 per disk), sporangia (75 per disk), or sporangia plus trifluoperazine hydrochloride (TFP) (75 per disk), a chemical that inhibits zoospore formation. Combining results from two different isolates, the highest concentration of zoospores $(2,400$ per disk) induced a significantly higher percentage of necrotic leaf disk area $(96.6 \%)$ than sporangia $(87.6 \%)$ and 500 zoospores per disk $(88.7 \%)$. The sporangia plus TFP treatment had the lowest necrosis at $47.5 \%$. Rooted rhododendron cuttings had a higher percentage of necrotic leaves per plant when inoculated with zoospores $(3,000$ or 50,000 per ml) or cysts $(50,000$ per ml) than with sporangia $(3,000$ per $\mathrm{ml})$ with or without TFP. The percentage of necrotic leaf area was significantly higher when cysts or zoospores were inoculated at 50,000 per ml than sporangia without TFP and zoospores at 3,000 per ml. All treatments were significantly higher in the percentage of necrotic leaf area than the leaves treated with sporangia plus TFP. This demonstrates that the full inoculum potential may not be achieved when sporangia are used as the inoculum propagule.
\end{abstract}

Phytophthora species are known to be destructive and complex plant pathogens. They produce combinations of different sexual and asexual propagules depending upon the species. The most common and characteristic asexual propagule is the sporangium (9). Some species have caducous sporangia that detach easily from the sporangiophore by wind or water, giving them the capacity to travel several kilometers to new host plants (2). Sporangia germinate either directly or indirectly by releasing zoospores that subsequently encyst and germinate. These two different processes are influenced by temperature change, relative humidity, the age of sporangia, and substrate $(21,28,31)$. Generally, at higher temperatures $\left(>14\right.$ to $20^{\circ} \mathrm{C}$, depending upon the species), direct germina-

\section{Corresponding author: Timothy Widmer E-mail: tim.widmer@ars.usda.gov}

The use of trade, firm, or corporation names in this publication is for the information and convenience of the reader. Such use does not constitute an official endorsement or approval by the United States Department of Agriculture or the Agricultural Research Service of any product or service to the exclusion of others that may be suitable.

Accepted for publication 17 September 2008.

doi:10.1094/PDIS-93-1-0030

This article is in the public domain and not copyrightable. It may be freely reprinted with customary crediting of the source. The American Phytopathological Society, 2009. tion occurs in which hyphae emerge through the wall of the sporangium (18). At lower temperatures, the sporangial cytoplasm cleaves and biflagellate zoospores are formed (16). The motile zoospores are released from the sporangium and recognize host tissue by chemical, electrical, and physical properties (36). The zoospores encyst, germinate, and penetrate susceptible host cells.

Phytophthora ramorum has a life cycle similar to that of other aerial-type Phytophthora spp., such as $P$. capsici and $P$. infestans. Wind and wind-driven rains are believed to spread the caducous $P$. ramorum sporangia within forest canopies (11) from which it is likely that zoospores are released from the sporangia and swim to new infection sites. Davidson et al. (7) observed abundant zoospores released from sporangia on infected bay laurel leaves under natural field conditions during rainstorms. In general, it is believed that infection of plant material via zoospores is the most important pathway in the disease cycle (18). However, the majority of previously published papers that involved screening hosts of $P$. ramorum used sporangia as the inoculum source (e.g., 25,32,35). Since a single $P$. ramorum sporangium can release, on average, 32 zoospores (personal observation), the actual number of potentially infective propagules derived from sporangia-based inoculum can be variable, depending upon the number of sporangia that actually release zoospores. It is generally assumed that the majority of sporangia will release zoospores; however, Judelson and Tani (20) reported that only $58 \%$ of $P$. infestans sporangia released zoospores when tested under artificial conditions. Factors including the solute potential and matric potential are known to affect sporangia releasing zoospores (27). It is not known what significance sporangia that have not released zoospores have via direct germination on disease development.

Studies involving other Phytophthora spp. sprayed zoospores to infect aerial plant parts to screen for resistance $(5,12,13,25,34)$. Several exceptions found in the literature that used $P$. ramorum zoospores as inoculum for aerial plant parts dipped the leaves in the suspension $(14,37,39)$. However, to the author's knowledge, no studies have actually been completed that directly compare infection by different propagule types of any Phytophthora spp. It is important to document if differences do exist between propagule types so that future experiments can be consistent while minimizing variability.

Phytophthora ramorum produces both chlamydospores and sporangia on tissue $(6,33)$. In general, $P$. ramorum chlamydospores are regarded as long-term survival structures that may initiate the polycyclic epidemic, but their impact on sustaining an epidemic has not been shown. Although chlamydospores have been observed on leaf surfaces (6), they are not easily detached from the mycelium like sporangia. Thus, it is unlikely that chlamydospores are significant in increasing secondary inoculum for a polycyclic epidemic, and they were not included in this study. Sporangia, on the other hand, have been observed on the surface of leaf material and are caducous, thus playing a major role in spread within a plant and from plant to plant $(6,18)$.

This study was conducted to determine what impact $P$. ramorum sporangia, zoospores, and cysts have on disease development of a susceptible host. This was done by comparing the necrotic leaf area caused by direct germination of sporangia or cysts.

\section{MATERIALS AND METHODS}

Pathogen isolates and inoculum preparation. Cultures of $P$. ramorum were obtained from P. W. Tooley (USDA-ARS, Fort Detrick, MD). Phytophthora ramorum isolates WSDA-1772, 5-C, and PRN-1 were used in different tests throughout the study. Isolate WSDA-1772 is an A2 mating 
type originally isolated from Viburnum 'Mariesii' in Oregon. Isolate 5-C is an A2 mating type originally isolated from $\mathrm{Ca}$ mellia sasanqua 'Bonanza' in California. Isolate PRN-1 is an A1 mating type originally isolated from Rhododendron sp. in The Netherlands. All isolates were maintained on $20 \% \mathrm{~V} 8$ agar at $20^{\circ} \mathrm{C}$ in the dark.

Zoospores were prepared by the method of Mitchell and Kannwischer-Mitchell (29). Five 4-mm plugs of each isolate were added to separate $60-\mathrm{mm}$ plates containing sterile $20 \%$ V8 broth. The cultures were allowed to grow for 3 days at $20^{\circ} \mathrm{C}$ in the dark. The mycelium was rinsed three times in sterile $0.1 \mathrm{mM}$ 2-[N-morpholino] ethanesulfonic acid (MES) buffer, $\mathrm{pH} 6.2$ (herein referred to as MES buffer) and then placed back in the $20^{\circ} \mathrm{C}$ incubator in the dark overnight. Zoospores were induced to release from the formed sporangia by placing the cultures at $4^{\circ} \mathrm{C}$ for $30 \mathrm{~min}$ and incubating at room temperature. After 30 to $45 \mathrm{~min}$, zoospores released and the concentration was determined by diluting the suspension in MES buffer, vortexing to induce encystment, and then counting on a hemacytometer. The zoospores were diluted to the final concentrations by carefully pipetting a specific amount in MES buffer. Motility of the zoospores was verified after dilution through a dissecting microscope.

For the leaf disk bioassay, sporangia were prepared by the method of Tooley et al. (35). Five-milliliter plugs from the edge of an actively growing $P$. ramorum culture on $20 \%$ V8 agar were removed and placed in at least two sterile $60-\mathrm{mm}$-diameter petri dishes. Enough MES buffer was poured into the dish to reach just below the top of the plugs. The plates were covered, but not sealed, and placed at $20^{\circ} \mathrm{C}$ in the dark overnight. Sporangia were released from the mycelium by sealing the plates with Parafilm and shaking the suspension. The suspensions of sporangia from multiple plates for each isolate were removed by pipette and combined into a $15-\mathrm{ml}$ conical tube. The suspension was mixed, and onehalf of it was transferred to another $15-\mathrm{ml}$ conical tube. The sporangial concentration was determined for each suspension by mixing well and placing two 25- $\mu$ l drops on a glass slide and counting all of the sporangia. A stock solution of $1.25 \mathrm{mM}$ trifluoperazine hydrochloride (TFP; Sigma Chemical Co.) was prepared in sterile water. The TFP stock solution was added to one of the sporangial suspensions to make a final concentration of $12.5 \mu \mathrm{M}$. Sporangia can be prevented from forming zoospores by exposure to TFP without preventing direct sporangial germination (19).

For the whole plant bioassay, sporangia were prepared by transferring a plug of the $P$. ramorum isolate to $20 \% \mathrm{~V} 8$ agar plates and placing in an incubator at $20^{\circ} \mathrm{C}$ in the dark. Sporangia were harvested from the plate after approximately 2 weeks by pouring $5 \mathrm{ml}$ of MES buffer onto the agar surface and gently swirling to release the sporangia from the mycelium. The suspension was pipetted off the surface into a 15$\mathrm{ml}$ conical tube. After vortexing, half of the suspension was transferred to another 15-ml conical tube. The concentration of sporangia was determined as described above. The final concentration was adjusted to 3,000 sporangia per $\mathrm{ml}$ in MES buffer. A quantity of the TFP stock solution was added to one of the sporangial suspensions to make a final concentration of 12.5 $\mu \mathrm{M}$.

Release and inhibition of zoospores from sporangial suspensions with or without TFP were conducted by exposing an aliquot of the suspensions to $4^{\circ} \mathrm{C}$ for 20 min and then incubating at room temperature for $45 \mathrm{~min}$. Direct germination of sporangia exposed to TFP was observed through a compound microscope with a $10 \times$ objective lens on a $20 \%$ V8 agar plate containing a sample of the sporangial suspension after $24 \mathrm{~h}$ in the dark at $20^{\circ} \mathrm{C}$. The effect of TFP on infection of rhododendron leaf disks was studied by placing 10 leaf disks (11-mm-diameter) abaxial side up on a plastic mesh screen on a moist filter paper in a petri dish. The epidermis of the abaxial side of each leaf disk was wounded slightly with a blunt scalpel. Thirty microliters of sterile distilled water or sterile $12.5 \mu \mathrm{M}$ TFP solution was pipetted onto the wound site. A 3-mm mycelial plug was removed from the edge of an actively growing culture on V8 agar of $P$. ramorum isolates 5-C, WSDA-1772, and PRN-1 and placed mycelium side down in the solution over the wound site. The plates were sealed and placed in a $20^{\circ} \mathrm{C}$ incubator in the dark for 3 days. The disks were photographed and the percent necrotic area was calculated using ASSESS (American Phytopathological Society) software. The experiment was conducted twice.

Sporangial discharge. The percentage of sporangia that released zoospores was calculated using a procedure modified from Jones et al. (17). Detached sporangia were produced as described above for isolates WSDA-1772, 5-C, and PRN-1 (35). Two 0.5-ml aliquots of each sporangial suspension were transferred to a 24well microtiter plate. The plate was placed at $4^{\circ} \mathrm{C}$ for $30 \mathrm{~min}$ and then transferred to an incubator at $20^{\circ} \mathrm{C}$ in the dark. After $4 \mathrm{~h}$, 100 randomly selected sporangia were observed to assess the percentage of sporangia releasing zoospores (i.e., empty sporangia). The experiment was conducted three times.

The impact on the sporangia discharging zoospores after passing through a handpump sprayer was assessed by preparing two 10-ml aliquots of sporangia (isolate WSDA-1772) as described above in MES buffer. One aliquot was poured directly into a $60-\mathrm{mm}$ petri plate. The other aliquot was transferred to a hand-pump sprayer and discharged through the sprayer into another $60-\mathrm{mm}$ petri plate. The plates were covered, but not sealed, placed at $4^{\circ} \mathrm{C}$ for 1 $\mathrm{h}$, returned to room temperature for $1 \mathrm{~h}$, and observed under a dissecting microscope for release. The percentage of empty sporangia was determined as described above. The experiment was conducted three times.

Leaf disk bioassay. Tests were conducted with $P$. ramorum isolates WSDA1772 and PRN-1. Individual healthy, mature leaves of Rhododendron 'Cunningham's White' were selected from at least 10 separate plants. The leaves were rinsed in water and blotted dry. Leaf disks were made with a cork borer (11-mm-diameter). The surface areas of the disks were not wounded and were placed abaxial side up on a plastic mesh screen on a moist filter paper in a petri dish. Ten disks were placed in a single petri dish, with two dishes for each treatment. Sporangial and zoospore suspensions were prepared as described above. If necessary, a volume of MES buffer was pipetted onto the disk surface to assure that the volume of liquid on each disk among the treatments was the same. The different treatment suspensions were pipetted onto the disk surface so that the liquid remained as a "bead" on the disk. The treatments were as follows: (i) MES buffer plus $12.5 \mu \mathrm{M}$ TFP (negative control); (ii) 75 sporangia suspended in MES buffer; (iii) 75 sporangia suspended in MES buffer plus $12.5 \mu \mathrm{M}$ TFP; (iv) 2,400 zoospores in MES buffer; (v) 500 zoospores in MES buffer; and (vi) 75 zoospores in MES buffer. The plates were covered, sealed, and placed at $20^{\circ} \mathrm{C}$ in the dark. Since zoospores are blocked from forming in sporangia at the concentration of TFP used in this experiment (19), a control with zoospores and TFP was not needed.

After 5 days, photographs of each of the disks were recorded and the percentage of necrotic leaf disk surface area was calculated for each disk using ASSESS and averaged together. The experiment was conducted four times for each concentration and propagule type of each $P$. ramorum isolate tested.

Comparing methods of cyst application. Due to mechanical agitation, active zoospores cannot be applied via a pressurized sprayer without the risk of encystment. However, it is more practical to apply the propagule with a pressurized sprayer. Since two application methods were used for the different propagule types, it was important to verify that the application method does not significantly impact the infection process and disease development. Zoospores of isolate WSDA1772 were produced by the methods described above and diluted in two 15-ml aliquots of 50,000 per $\mathrm{ml}$. Both aliquots were vigorously shaken on a vortex shaker 
without TFP treatment, and both were statistically greater than the sporangial suspension with TFP.

\section{DISCUSSION}

The result trends from this study were similar whether whole plants or leaf disks were used. The data show that without zoospore release, direct germination of $P$. ramorum sporangia is not as effective in causing necrosis as an equivalent number of zoospores. This supports the recommendation that zoospores or cysts rather than sporangia should be used as the inoculum propagule when screening potential hosts against $P$. ramorum, as has been utilized for other Phytophthora spp. $(5,24,34)$.

One drawback mentioned with the use of sporangia as the inoculum type is the uncertainty that all sporangia will release zoospores. In this study, the vast majority (average of 93\%) of sporangia released zoospores after $4 \mathrm{~h}$ when produced at $20^{\circ} \mathrm{C}$ in liquid culture, exposed to $4^{\circ} \mathrm{C}$ for $1 \mathrm{~h}$, and returned to $20^{\circ} \mathrm{C}$. This is higher than the number observed for $P$. infestans, which ranged from $58 \%$ (20) to $74 \%$ (19), and $P$. parasitica, which discharged $73 \%$ of the time (38). For all of these results, including the present study, these tests were conducted under ideal conditions that are unlikely on a leaf surface. The phylloplane is a complex microenvironment influenced by microorganisms and leaf exudations. One aspect of leaf exudations is the solute potential that is dependent upon environmental and genetic factors $(23,26)$. MacDonald and Duniway (27) demonstrated that the solute potential affects zoospore release from sporangia. In one study, it was demonstrated that the host plant affected the release of Plasmopara viticola zoospores from sporangia (22). Temperature of the culture growth also plays an important role in zoospore release. In this study, cultures were grown only at one temperature, $20^{\circ} \mathrm{C}$. When Davidson et al. (7) produced sporangia on California bay laurel (Umbellularia californica) disks at different temperatures, large differences between trials in zoospore release after $30 \mathrm{~min}$ exposure at $4^{\circ} \mathrm{C}$ were observed at the $25^{\circ} \mathrm{C}$ treatment. These factors demonstrate that different aspects affect zoospore release and that the full inoculum potential may not be realized when using sporangia alone as the inoculum propagule.

For whole plants, the number of necrotic leaves per plant was higher when zoospores were applied as the inoculum source, but the percentage of necrotic leaf area was not different from that of cysts. This lack of difference between zoospores and cysts is important because there are advantages to using these propagules as the inoculum type. First, a hand-pump sprayer is ideal for applying large amounts of inoculum in a quick and efficient manner that can easily cover all plant parts. In this experiment, the method for applying cysts to leaves, by using either a handpump sprayer or a paintbrush, did not affect the percentage of necrotic leaf area. This comparison could not be done with zoospores because it cannot be assured that all zoospores will remain motile when subjected to conditions of agitation when passing through a sprayer. In addition, care must be taken as to the type of pump sprayer used in application. The application pressure and use of carbon dioxide affected the survival of Phytophthora nicotianae zoospores (3). Secondly, inoculum levels can be more carefully controlled and applied homogenously using cysts compared to sporangia because of the uncertainty as to how many or if any zoospores are released from the sporangia. As mentioned above, not all sporangia may release zoospores depending upon different factors. Therefore, if sporangia are applied, actual inoculum potential due to the number of actual infective propagules released may vary within an experiment. Using cysts as the inoculum type would reduce the error of variable laboratory conditions affecting zoospore release on the host, assuring that the full potential of infective propagules are in contact with the host. In this study, higher variability in the mean percentage of necrotic leaf disk surface area (Table 1) and in the percentage of necrotic leaves per plant (Table 2) was observed when sporangia were used as the inoculum type compared to zoospores or cysts. Lastly, it is more time-consuming to produce abundant quantities of sporangia in concentrations useful for larger-scale inoculation trials than cysts. Typical methods require from 1 to 2 weeks to produce sporangia for inoculum and may require centrifugation for adequate concentrations (35). In contrast, high concentrations of zoospores can be achieved in liquid cultures in 4 days.

Table 2. Mean percentage of necrotic Rhododendron 'Cunningham's White' leaves per plant and mean percentage of necrotic leaf area inoculated with different propagules and concentrations of Phytophthora ramorum isolate WSDA-1772

\begin{tabular}{|c|c|c|c|}
\hline Treatment $^{\mathrm{v}}$ & $\begin{array}{c}\text { Propagule } \\
\text { concentration per ml }{ }^{\mathrm{w}}\end{array}$ & $\begin{array}{c}\text { Mean \% }( \pm \mathrm{SE}) \text { of necrotic } \\
\text { leaves per plant } \mathrm{x}^{\mathrm{x}}\end{array}$ & $\begin{array}{c}\text { Mean \% }( \pm \mathrm{SE}) \\
\text { of necrotic leaf area }\end{array}$ \\
\hline Sporangia-TFP & 3,000 & $76.1 \% \pm 5.09 \mathrm{C}^{\mathrm{z}}$ & $37.6 \% \pm 3.62 \mathrm{~B}$ \\
\hline Sporangia + TFP & 3,000 & $65.7 \% \pm 4.91 \mathrm{C}$ & $25.1 \% \pm 3.46 \mathrm{C}$ \\
\hline Cysts & 50,000 & $89.0 \% \pm 2.91 \mathrm{~B}$ & $56.6 \% \pm 3.51 \mathrm{~A}$ \\
\hline Zoospores & 50,000 & $97.3 \% \pm 1.89 \mathrm{~A}$ & $66.2 \% \pm 3.07 \mathrm{~A}$ \\
\hline Zoospores & 3,000 & $88.9 \% \pm 3.39 \mathrm{~B}$ & $41.9 \% \pm 4.98 \mathrm{~B}$ \\
\hline
\end{tabular}

${ }^{v}$ Propagule type of $P$. ramorum suspended in $0.1 \mathrm{mM} \mathrm{2-[N \text {-morpholino]ethanesulfonicacid(MES) }}$ buffer, $\mathrm{pH}$ 6.2, used to inoculate rhododendron plants. Trifluoperazine hydrochloride (TFP) was added (sporangia + TFP) or not added (sporangia - TFP) to suspensions of sporangia before application to plants.

w Propagule concentration in $15 \mathrm{ml}$ applied to five rhododendron plants for each repetition.

${ }^{x}$ A leaf was considered necrotic if the percentage of necrosis, as determined by ASSESS software, was greater than the control average (1.3\%). Percentage of leaves infected per plant was calculated by subtracting the number of infected leaves from the total number of leaves and dividing by the total number of leaves.

${ }^{y}$ Mean percentage of necrotic leaf area was calculated by dividing the total area of necrosis for an individual infected leaf into the total area of that leaf as calculated by ASSESS software.

${ }^{\mathrm{z}}$ Mean values within a column followed by the same letter are not significantly different $(P=0.05)$ according to Duncan's multiple range test. 
been above a threshold needed for disease development that compensated for the lack of motility and attraction toward open wounds. Tooley et al. (35) found that disease developed on bearberry (Arctostaphylos uva-ursi) and mountain laurel (Kalmia latifolia 'Minuet') when inoculated with as few as $100 \mathrm{P}$. ramorum sporangia per $\mathrm{ml}$, which if all discharged would equal approximately 3,000 zoospores. This study showed that necrosis occurred on leaf disks when inoculated with only 75 zoospores. In a field study involving $P$. capsici (30), inoculum density was shown not to be significant in the final disease incidence, although the data did show an impact of inoculum density on the area under the disease progress curves (AUDPC). The difference in AUDPC in that study was related most likely to the higher disease incidence at the initial recording of data.

Information obtained from this study helps us understand the epidemiology of this pathogen in the field. Previous studies demonstrated that under laboratory conditions, sporangia are produced at temperatures ranging from 5 to $30^{\circ} \mathrm{C}$ with an optimum temperature range of 16 to $22^{\circ} \mathrm{C}$ $(7,8)$. Therefore, daily temperature fluctuations between 10 and $22^{\circ} \mathrm{C}$, along with a minimum time of 6 to $12 \mathrm{~h}$ of free standing water (10), should promote sporangia formation and zoospore release, resulting in a higher rate of infection. In contrast, $25^{\circ} \mathrm{C}$ might be a threshold temperature for direct germination of sporangia versus zoospore production (7). Thus, based upon results from the present study, new infections by $P$. ramorum could be higher when field temperatures are below $25^{\circ} \mathrm{C}$ due to an increase in zoospore release. This model fits what was observed in the field in California. A study by Anacker et al. (1) revealed that symptomatic leaf count of $U$. californica was related to mean minimum annual temperature and the mean annual precipitation at the field plot level. Phytophthora ramorum populations, as measured by colony forming units, in the soil and leaf litter increased in the cooler middle to late rainy seasons (7). These higher populations are very likely due to an increase in zoospore release.

The results presented in this study confirm the importance of zoospore release by sporangia on the leaf surface in regard to infection and subsequent disease symptoms. Although sporangia that do not release zoospores still infect leaves and cause leaf necrosis, the number of leaves that are infected per plant and the mean percentage of necrotic leaf area are lower than an equivalent number of zoospores. This knowledge could lead to research that is more efficient in developing methods, either through chemicals or through integrated pest management options, to manage and limit the spread of this pathogen.

\section{ACKNOWLEDGMENTS}

I thank Nina Shishkoff, Paul Tooley, and the anonymous reviewers for their reviews and helpful suggestions to improve this manuscript.

\section{LITERATURE CITED}

1. Anacker, B. L., Rank, N. E., Hüberli, D., Garbelotto, M., Gordon, S., Harnik, T., Whitkus, R., and Meentemeyer, R. 2008. Susceptibility to Phytophthora ramorum in a key infectious host: Landscape variation in host genotype, host phenotype, and environmental factors. New Phytol. 177:756-766.

2. Aylor, D. E. 2003. Spread of plant disease on a continental scale: Role of aerial dispersal of pathogens. Ecology 84:1989-1997.

3. Banko, T. J., Richardson, P. A., and Hong, C. X. 2006. Effects of zoospore concentration and application pressure on foliage blight of $\mathrm{Ca}$ tharanthus roseus caused by Phytophthora nicotianae. Plant Dis. 90:297-301.

4. Biles, C. L., Bruton, B. D., Wall, M. M., and Rivas, M. 1995. Phytophthora capsici zoospore infection of pepper fruit in various physical environments. Proc. Okla. Acad. Sci. $75: 1-5$.

5. Colon, L. 1994. Resistance to Phytophthora infestans in Solanum tuberosum and wild Solanum species. Ph.D. thesis. Wageningen Agricultural University, Wageningen, The Netherlands.

6. Davidson, J. M., Rizzo, D. M., Garbelotto, M., Tjosvold, S., and Slaughter, G. W. 2002. Phytophthora ramorum and sudden oak death in California: II. Transmission and survival. Pages 741-749 in: Fifth Symposium on California Oak Woodlands. R. Standiford and D. McCreary, eds. USDA Forest Service, General Technical Report PSW-GTR-184, Albany, CA.

7. Davidson, J. M., Wickland, A. C., Patterson, H. A., Falk, K. R., and Rizzo, D. M. 2005. Transmission of Phytophthora ramorum in mixed-evergreen forest in California. Phytopathology 95:587-596.

8. Englander, L., Browning, M., and Tooley, P. W. 2006. Growth and sporulation of Phytophthora ramorum in vitro in response to temperature and light. Mycologia 98:365-373.

9. Erwin, D. C., and Rebeiro, O. K. 1996. Phytophthora Diseases Worldwide. American Phytopathological Society, St. Paul, MN.

10. Garbelotto, M., Davidson, J. M., Ivors, K., Maloney, P., Hüberli, D., Koike, S. T., and Rizzo, D. M. 2003. Non-oak native plants are main hosts for sudden oak death pathogen in California. Calif. Agric. 57:18-23.

11. Goheen, E. M., Hansen, E., Kanaskie, A., Osterbauer, N., Parke, J., Pscheidt, J., and Chastagner, G. 2006. Sudden oak death and Phytophthora ramorum: A guide for forest managers, Christmas tree growers, and foresttree nursery operators in Oregon and Washington. Oregon State Univ. Ext. Publ. EM 8877.

12. Grenville-Briggs, L. J., Aurova, A. O., Bruce, C. R., Williams, A., Whisson, S. C., Birch, P. R. J., and van West, P. 2005. Elevated amino acid biosynthesis in Phytophthora infestans during appressorium formation and potato infection. Fungal Gen. Biol. 42:244-256.

13. Hansen, E. M., Hamm, P. B., and Roth, L. F. 1989. Testing Port-Orford-cedar for resistance to Phytophthora. Plant Dis. 73:791-794.

14. Hansen, E. M., Parke, J. L., and Sutton, W. 2005. Susceptibility of Oregon forest trees and shrubs to Phytophthora ramorum: A comparison of artificial inoculation and natural infection. Plant Dis. 89:63-70.

15. Hardham, A. R. 2007. Cell biology of plantoomycete interactions. Cell. Microbiol. 9:3139.

16. Hardham, A. R., and Hyde, G. J. 1997. Asexual sporulation in the Oomycetes. Adv. Bot. Res. 24:353-398.
17. Jones, E. S., Breese, W. A., and Shaw, D. S. 2001. Inoculation of pearl millet with the downy mildew pathogen, Sclerospora graminicola: Chilling inoculum to delay zoospore release and avoid spray damage to zoospores. Plant Pathol. 50:310-316.

18. Judelson, H. S., and Blanco, F. A. 2005. The spores of Phytophthora: Weapons of the plant destroyer. Nat. Rev. Microbiol. 3:47-58.

19. Judelson, H. S., and Roberts, S. 2002. Novel protein kinase induced during sporangial cleavage in the oomycete Phytophthora infestans. Eukaryotic Cell 1:687-695.

20. Judelson, H. S., and Tani, S. 2007. Transgeneinduced silencing of the zoosporogenesisspecific NIFC gene cluster of Phytophthora infestans involves chromatin alterations. $\mathrm{Eu}-$ karyotic Cell 6:1200-1209.

21. Jung, T., Nechwatal, J., Cooke, D. E. L., Hartmann, G., Blaschke, M., Oßwald, W. F., Duncan, J. M., and Delatour, C. 2003. Phy tophthora pseudosyringae sp. nov., a new species causing root and collar rot of deciduous tree species in Europe. Mycol. Res. 107:772-789.

22. Kiefer, B., Riemann, M., Büche, C. Kassemeyer, H. H., and Nick, P. 2004. The host guides morphogenesis and stomatal targeting in the grapevine pathogen Plasmopara viticola. Planta 215:387-393.

23. Kumar, A., and Singh, D. P. 1998. Use of physiological indices as a screening technique for drought tolerance in oilseed Brassica species. Ann. Bot. 81:413-420.

24. Lee, B. K., Kim, B. S., Chang, S. W., and Hwang, B. K. 2001. Aggressiveness to pumpkin cultivars of isolates of Phytophthora capsici from pumpkin and pepper. Plant Dis. 85:497-500.

25. Linderman, R. G., and Davis, E. A. 2007. Evaluation of Phytophthora ramorum in nursery crop tissue culture propagation. Online. Plant Health Progress doi:10.1094/PHP-20070822-01-RS.

26. Loach, K. 2006. Leaf water potential and the rooting of cuttings under mist and polythene. Physiol. Plant. 40:191-197.

27. MacDonald, J. D., and Duniway, J. M. 1978. Influence of the matric and osmotic components of water potential on zoospore discharge in Phytophthora. Phytopathology 68:751-757.

28. Minogue, K. P., and Fry, W. E. 1981. Effect of temperature, relative humidity, and rehydration rate on germination of dried sporangia of Phy tophthora infestans. Phytopathology 71:11811184

29. Mitchell, D. J., and Kannwischer-Mitchell, M. E. 1992. Phytophthora. Pages 31-38 in: Methods for Research on Soilborne Phytopathogenic Fungi. L. L. Singleton, J. D. Mihail, and C. M. Rush, eds. American Phytopathological Society, St. Paul, MN

30. Ristaino, J. B. 1991. Influence of rainfall, drip irrigation, and inoculum density on the development of Phytophthora root and crown rot epidemics and yield in bell pepper. Phytopathology 81:922-929.

31. Sato, N. 1994. Effect of some inorganic salts and hydrogen ion concentration on direct germination of the sporangia of Phytophthora in festans. Ann. Phytopathol. Soc. Jpn. 60:441447.

32. Shishkoff, N. 2007. Susceptibility of some Lilac cultivars and other members of the Oleaceae to Phytophthora ramorum. Online. Plant Health Progress doi:10.1094/PHP-20071101-02-RS.

33. Shishkoff, N. 2007. Persistence of Phytophthora ramorum in soil mix and roots of nursery ornamentals. Plant Dis. 91:1245-1249.

34. Stewart, H. E., Flavelle, P. H., McCalmont, D. C., and Wastie, R. L. 1983. Correlation between glasshouse and field tests for resistance 
to foliage blight caused by Phytophthora infestans. Potato Res. 26:41-48.

35. Tooley, P. W., Kyde, K. L., and Englander, L. 2004. Susceptibility of selected ericaceous ornamental host species to Phytophthora ramorum. Plant Dis. 88:993-999.

36. Tyler, B. M. 2002. Molecular basis of recognition between Phytophthora pathogens and their hosts. Annu. Rev. Phytopathol.
40:137-167.

37. Vettraino, A. M., Hüberli, D., Swain, S., Smith, A., and Garbelotto, M. 2006. A new report of Phytophthora ramorum on Rhamnus purshiana in northern California. Plant Dis. 90:246.

38. von Broembsen, S. L., and Deacon, J. W. 1997. Calcium interference with zoospore biology and infectivity of Phytophthora parasitica in nutrient irrigation solutions. Phytopathology 87:522-528.

39. Wagner, S., Kaminski, K., and Werres, S. 2005. Inoculation trials with Phytophthora ramorum on Moorland species. Pages 520-522 in: Proc. Sudden Oak Death 2nd Symposium: The State of Our Knowledge. U.S. Dep. Agric. For. Serv., Pacific Southwest Res. Stn., Gen. Tech. Rep. PSW-GTR-196. Albany, CA. 